\title{
Cattle use affects forage quality in a montane riparian ecosystem
}

\author{
REBECCA L. PHILLIPS, M.J. TRLICA, WAYNE C. LEININGER, AND WARREN P. CLARY
}

Authors are research assistant, Graduate Degree Program in Ecology, Colorado State University; professor and associate professor, Rangeland Ecosystem Science Department, Colorado State University, Fort Collins, Colo. 80523; and project leader, Intermountain Research Station, Boise, Idaho 83702.

\begin{abstract}
Forage nitrogen $(\mathrm{N})$ and phosphorous $(\mathrm{P})$ concentrations and in-vitro dry-matter digestibility (IVDMD) were measured in 2 important riparian species the year following short-term, high-intensity cattle grazing treatments in a montane riparian ecosystem in northcentral Colorado. Current year's growth of water sedge (Carex aquatilus Wahlenb.) and planeleaf willow (Salix planifolia Pursh.) was collected monthly from May to September 1996. The effects of grazing and season of grazing in 1995 on forage quality the following growing season was determined. Season of grazing (i.e., latespring, early-summer, late-summer, and fall) the previous year did not differentially affect forage quality in either species. However, grazing by cattle the previous year did increase forage quality of water sedge as compared with plants that were not previously grazed. Grazed water sedge plants had higher concentrations of $N$ and $P$ and greater IVDMD than ungrazed controls. Nitrogen and $P$ concentrations of browsed planeleaf willow were not different from controls, but current year's growth collected in the fall from previously browsed plants was $11 \%$ more digestible than current year's growth from non-browsed willow. The 2 species responded uniquely to cattle use, which suggested that these 2 life forms differ in response to herbivory. This study supported the hypothesis that grazing by cattle would improve forage quality in a riparian ecosystem, although results varied with life form.
\end{abstract}

Key Words: Water sedge, Carex aquatilus, planeleaf willow, Salix planifolia, nitrogen, phosphorous, in-vitro dry-matter digestibility

Previous studies have shown that large herbivores utilize riparian areas disproportionately heavy relative to upland areas (Roath and Krueger 1982, Platts and Nelson 1985). Heavy grazing might change plant species composition, production, stand density, vigor, and seed production (Ryder

Research was funded by the U.S. Forest Service Research Joint Venture Agreement INT-96080-RJVA and the Colorado State University Agricultural Experiment Station.

The authors would like to thank Dr. James Detling for his critical review of the manuscript. The U.S. Forest Service is recognized for granting permission to use land and other resources for this study. We also thank Barbara Oskroba for her assistance and use of facilities for conducting the laboratory analyses.

Manuscript accepted15 Aug. 1998.

\section{Resumen}

Se midió la concentración de nitrógeno $(\mathrm{N})$ y fósforo $(\mathbf{P})$ del forraje y la digestibilidad in vitro de la materia seca (DIVMS) de 2 importantes especies ribereñas. Las mediciones fueron hechas al año siguiente de aplicar con ganado los tratamientos de apacentamiento de corta duración y alta intensidad en un ecosistema ribereño de montaña de la región norcentral de Colorado. El crecimiento de "water sedge" (Carex aquatilus Wahlenb.) y "planeleaf willow" (Salix planifolia Pursh.)se registró mensualmente de mayo a septiembre de 1996. Se determinaron los efectos que el apacentamiento y la época de apacentamiento de 1995 tuvieron en la calidad del forraje de la siguiente estación de crecimiento. La época de apacentamiento (por ejemplo, fin de primavera, inicio de verano, fin de verano y otoño) del año anterior no afecto la calidad de forraje de ninguna de las especies. Sin embargo, el apacentamiento con ganado en el año anterior incrementó la calidad del forraje de "water sedge" ya que fue superior a la de plantas que no fueron apacentadas anteriormente. Las plantas apacentadas de "water sedge" tuvieron mayores concentraciones de nitrógeno y fósforo y mayor DIVMS que las plantas control sin apacentamiento. La concentración de $\mathbf{N}$ y $\mathbf{P}$ de plantas ramoneadas de "planeleaf willow" fueron similares a las de las plantas control, pero el forraje colectado en otoño de plantas anteriormente ramoneadas fue $11 \%$ más digestible en comparación del forraje producido en la misma época por plantas intactas de "planeleaf willow". Las 2 especies respondieron en forma única al uso por el ganado, lo cual sugiere que estas dos formas de vida responden en forma diferente a la herbívora. Este estudio soporta la hipótesis de que el apacentamiento por ganado podría mejorar la calidad del forraje de los ecosistemas ribereños, aunque los resultados varían con la forma de vida.

1980), and several investigators have observed changes in riparian vegetation biomass, height, composition, and cover in response to specific grazing regimes (Kauffman et al. 1983, Schulz and Leininger 1990, Popolizio et al. 1994, Clary 1995). Nutritive quality of forage species following grazing has not been determined for montane riparian ecosystems, and data that indicate how livestock grazing affects forage quantity in riparian ecosystems are needed for better management of riparian grazing (Platts 1986). 
Two common montane riparian species, water sedge (Carex aquatilus Wahlenb.) and planeleaf willow (Salix planifolia Pursh.), were evaluated to determine how previous cattle use affected forage $\mathrm{N}$ and $\mathrm{P}$ concentrations and IVDMD. Plants were evaluated at 4 phenological stages of plant development following 1 year of short-term, high intensity grazing treatments in an area that had been excluded from cattle grazing for 40 years. It was hypothesized that water sedge and planeleaf willow would have increased $\mathrm{N}$ concentration in current year's growth after grazing, along with concomitant levels of increased $\mathrm{P}$ and digestibility. Other researchers have reported elevated $\mathrm{N}$ concentrations for upland graminoid species from 4 weeks to 6 months after defoliation (Jaramillo and Detling 1988, Polley and Detling 1988, Rhodes and Sharrow 1990). This study, however, was conducted 8-12 months following cattle use treatments, and riparian rather than upland species were evaluated.

\section{Materials and Methods}

\section{Study Site}

The Sheep Creek Allotment is located in north central Colorado, $80 \mathrm{~km}$ northwest of Fort Collins, within the Roosevelt National Forest at an elevation of approximately $2,500 \mathrm{~m}$. The Allotment consists of 5,340 ha with 1,050 ha classified as grazeable range. The riparian area was heavily grazed from the 1890's to the mid-1950's. Three exclosures comprising a total of 40 ha and $2.5 \mathrm{~km}$ of stream and adjacent riparian meadows were constructed in 1956 to exclude cattle use (Schulz and Leininger 1990, Popolizio et al. 1994). The study plots (paddocks), located within these exclosures, had been protected for 40 years.

The nearest weather station to Sheep Creek is located at Red Feather Lakes, $15 \mathrm{~km}$ southeast of the study site at an elevation of $2,542 \mathrm{~m}$. Average annual precipitation at Red Feather Lakes is $406 \mathrm{~mm}$, while average precipitation for the growing season (May-September) is $236 \mathrm{~mm}$. Average daily temperatures range from $-11^{\circ} \mathrm{C}$ in January to $25^{\circ} \mathrm{C}$ in July, and average daily temperatures during the growing season range from $0^{\circ}$ to $25^{\circ} \mathrm{C}$ (National Climatic Data
Center 1948-1990). For the study period, average growing season precipitation at the Red Feather Lakes weather station was $285 \mathrm{~mm}$, and temperatures ranged from $4^{\circ}$ to $16^{\circ} \mathrm{C}$ (NOAA 1995 1996).

The Naz soil series dominates the Sheep Creek region. These are deep, well drained soils formed from granitic parent material. Soils in the riparian study areas are primarily Naz 70, with 1 to $3 \%$ slopes. Texture of the soil is a clay loam and is classified as coarse loamy pachic cryoborol. The A horizon has high organic matter (4-17\%) and is from 20 to $80 \mathrm{~cm}$ thick (USDA 1980).

Overstory vegetation at the study site was dominated by planeleaf willow, Geyer willow ( $S$. geyeriana Anderss.), and yellow willow ( $S$. lutea Nutt.). Understory herbaceous vegetation consisted of Kentucky bluegrass ( $P o a$ pratensis L.), fowl bluegrass ( $P$. palustris L.), water sedge, Nebraska sedge ( $C$. nebraskensis Dewey), beaked sedge ( $C$. rostrata Stokes), tufted hairgrass (Deschampsia caespitosa L.), bluejoint reedgrass (Calamagrostis canadensis Michx.), and dandelion (Taxaxacum officinale Wiggers) (Schulz and Leininger 1991, Popolizio et al. 1994).

\section{Methods}

Small (0.25 ha) paddocks utilized in this study were randomly located within the exclosures. Short-duration, highintensity, seasonal grazing treatments with steers were applied in these paddocks in 1995. A set of 3 replicated paddocks that represented each of 5 grazing treatments; late-spring, early-summer, late-summer, fall, and control (not grazed) were assigned at random to the paddocks. Five steers were placed in the designated paddocks at the beginning of each season and allowed to graze until herbaceous utilization reached approximately 65\% (Pelster 1998). The average time to reach this level of utilization was approximately 4 days. According to the stubble-height measurement technique (Kinney and Clary 1994), 65\% percent of the herbaceous biomass was utilized, and utilization of individual plants within a paddock was fairly consistent. All willow plants within each paddock were browsed to a height of $2 \mathrm{~m}$, although the proportion of willow in cattle diets gradually increased from late-spring to fall 1995 (Pelster 1998). The forage quality in the 2 contrasting species was determined the year following grazing.

Random samples were taken for both species within each paddock 4 times during the 1996 growing season. Initial forage samples were gathered from all paddocks 1 June, representing earlyspring growth. Early-summer, late-summer, and fall samples were taken at the beginning of each successive month thereafter. These collection times corresponded to the periods of the 1995 grazing treatments: late-spring, early-summer, late-summer, and fall. Grab samples of water sedge leaves and culms were clipped, while leaves and stem tips of current year's growth were removed by hand from planeleaf willow throughout each paddock. Forage samples for willows were taken only to a height of 2 $\mathrm{m}$ to insure that samples represented previously-browsed regrowth. Leaf and stem tissue of water sedge was clipped at ground level within each paddock and bagged as a sample. A total of 60 samples for each species, (5 grazing treatments x 4 dates of collection x 3 paddocks) were collected.

Forage samples were placed in paper bags, oven-dried at $50^{\circ} \mathrm{C}$, weighed, and ground through a $1-\mathrm{mm}$ mesh screen. Each homogenized sample represented a species within a paddock at a particular time for a grazing treatment. Carbon and nitrogen contents were determined using a LECO CHN-1000 instrument (LECO Corp. 1993). An acid digest was performed after samples were ashed in a muffle furnace at $500^{\circ} \mathrm{C}$. The digest was analyzed for $\mathrm{P}$ content with an inductively coupled plasma atomic emissions spectrometer (Baker et al. 1964). The IVDMD was determined following the procedure of Tilley and Terry (1963), as modified by Pearson (1970). Each sample was inoculated with ruminal fluid obtained from a fistulated steer on an alfalfa hay diet and allowed to digest for 48 hours at $39^{\circ} \mathrm{C}$. This was followed by an acid pepsin digest for an additional 48 hours to simulate digestion of material leaving the rumen.

All data were analyzed using analysis of variance techniques for a completely randomized block design with a factorial arrangement of treatments. Data for each species were analyzed separately and collectively using the SAS (1996) general linear models procedure. A repeated measures procedure was used to determine significant effects $(p<0.10)$ 
of collection time, species, grazing treatment, and interactions. Differences between grazed plants (all seasonal treatments combined) versus those that were not grazed (control) were compared using a linear contrast statement (SAS 1996). Five models tested the main factors of interest: a) a multivariate repeated measures analysis of variance that included grazing treatments and both species to determine species-level differences and three-way interactions, b) 2 multivariate repeated measures models, 1 for each species, where the variance among all treatments at each collection time was determined, and c) 2 univariate models, 1 for each species, that contrasted the grazed (all 4 seasonal treatments combined) plants with those that were not used by cattle (control).

\section{Results and Discussion}

A multivariate repeated measures analysis of variance revealed that collection time was a significant factor for both species $(p<0.01)$ for levels of $\mathrm{N}, \mathrm{P}$, and IVDMD $\left(\underline{\mathrm{F}}_{3,61}=303.4,255.8\right.$, 40.97 , respectively). Nitrogen and $\mathrm{P}$ concentrations and IVDMD, including all grazing treatments plus controls, decreased in both water sedge and planeleaf willow as phenological development continued from young leaves and shoots to senescence (Fig. 1, 2, 3).

\section{Water Sedge}

Average $\mathrm{N}$ concentration in water sedge of all treatments and controls was $2.5 \%$ on 1 June. Average $\mathrm{N}$ declined approximately $20 \%$ each successive month, to $1.3 \% \mathrm{~N}$ on 1 September (Fig. 1). Phosphorous decreased each month from a high of $0.34 \%$ on 1 June to a low of $0.11 \%$ on 1 September (Fig. 2). The IVDMD for water sedge, however, did not steadily decline over the growing season (Fig. 3). Average IVDMD for water sedge ranged from $68 \%$ in earlyspring to $54 \%$ in the fall. Sharp declines in IVDMD were found between latespring and early-summer samples (7\%) and between late-summer and fall samples $(12 \%)$. The decline in water sedge IVDMD between early-summer and late-summer, however, was only $1.6 \%$. Digestibility values between early- and late-summer remained about $63 \%$, which contrasts with the progressive

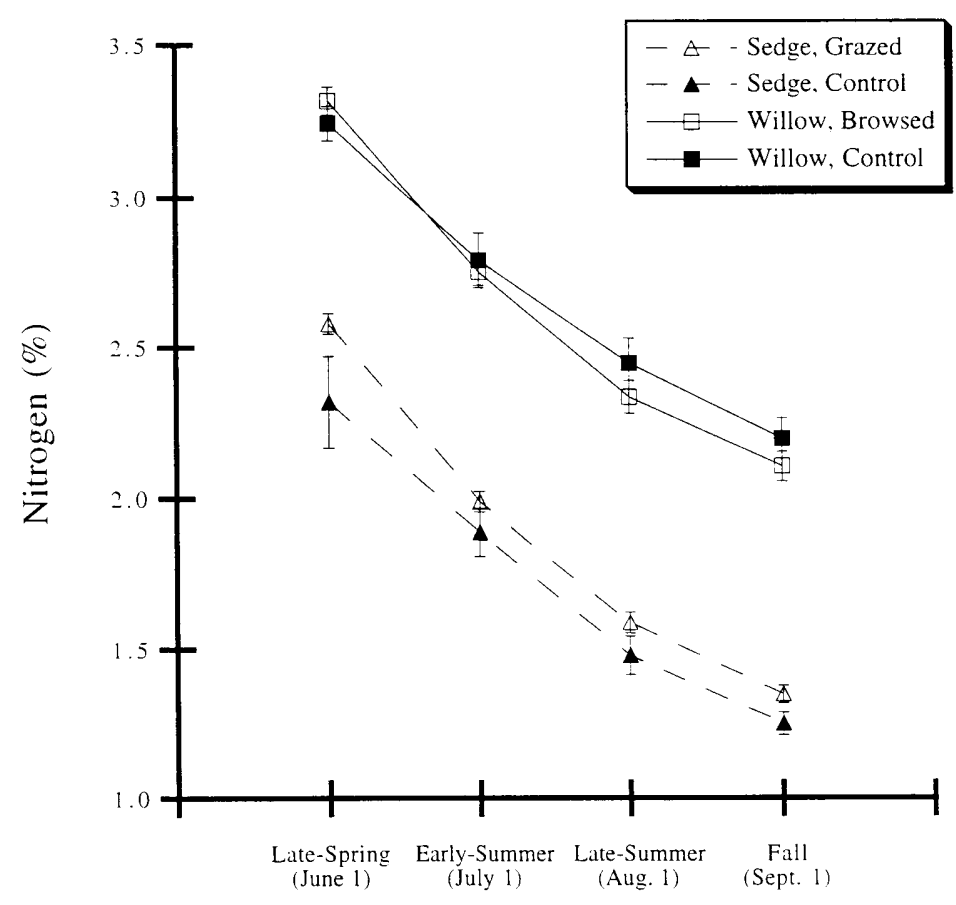

Collection Times

Fig. 1. Nitrogen concentration in current year's growth for grazed and ungrazed plants of 2 riparian species, water sedge (Carex aquatilus) and planeleaf willow (Salix planifolia). Data points represent means ( \pm standard error) for the dates that samples were collected. Collection times correspond with the following seasons: late-spring (1 June), early-summer (July 1), late-summer (1 Aug.), and fall (1 Sept.).

decline found for $\mathrm{N}$ and $\mathrm{P}$ over the summer. Nitrogen and $\mathrm{P}$ were not good predictors of digestibility, and differences in the seasonal patterns of $\mathrm{N}$ and $\mathrm{P}$ as compared with IVDMD indicated that other factors, such as fiber or secondary chemicals, influenced digestibility.

Water sedge nutritive characteristics varied seasonally, and comparative research that includes riparian forage quality data throughout an entire growing season is lacking. Coppock et al. (1983) reported $\mathrm{N}$ concentrations of 1.0 to $1.7 \%$ and IVDMD values from 52 to $63 \%$ over the growing season from May to October for Carex spp. in a mixedgrass prairie. At the Central Plains Experimental Range, N concentration and IVDMD for Bouteloua gracilis (H.B.K.) at peak standing crop (September 1) contained about $1.8 \% \mathrm{~N}$ and was 60-65\% digestible (Milchunas et al. 1995). A native sedge of Serengeti National Park in Tanzania, Kyllinga nervosa (Steud.), had $\mathrm{N}$ concentrations of $2-3 \%$ and $\mathrm{P}$ concentrations of $0.2 \%$ during the growing season (McNaughton and Chapin 1985). All these data are within the range reported for water sedge in the present study.
The comparable changes in $\mathrm{N}$ and $\mathrm{P}$ concentrations and IVDMD in water sedge between grazed and control plants with season of cattle use showed no significant collection time by grazing treatment interactions. Therefore, a simple effect of grazing was determined with a linear contrast statement (SAS 1996). This analysis combined the 4 seasonal grazing treatments and compared the forage quality with ungrazed plants. Results showed that grazed water sedge $\mathrm{N}$ and $\mathrm{P}$ concentrations and IVDMD were greater $(p<0.10)$ compared with plants that were not previously grazed, $\left(\underline{\mathrm{F}}_{3,30}=3.21,6.14,17.97\right.$, respectively $)$. Nitrogen in grazed water sedge was 5 to $10 \%$ higher than in comparable ungrazed plants (Fig. 1). Grazed water sedge plants remained higher in $\mathrm{N}$ than ungrazed plants throughout the entire growing season. Phosphorous concentrations were also higher in grazed water sedge (Fig. 2). At the beginning of the growing season, grazed plants were $14 \%$ higher in $\mathrm{P}$ than ungrazed plants. This differential declined from about $12 \%$ in July and August to < $1 \%$ in September. Thus, the effect of grazing on water 


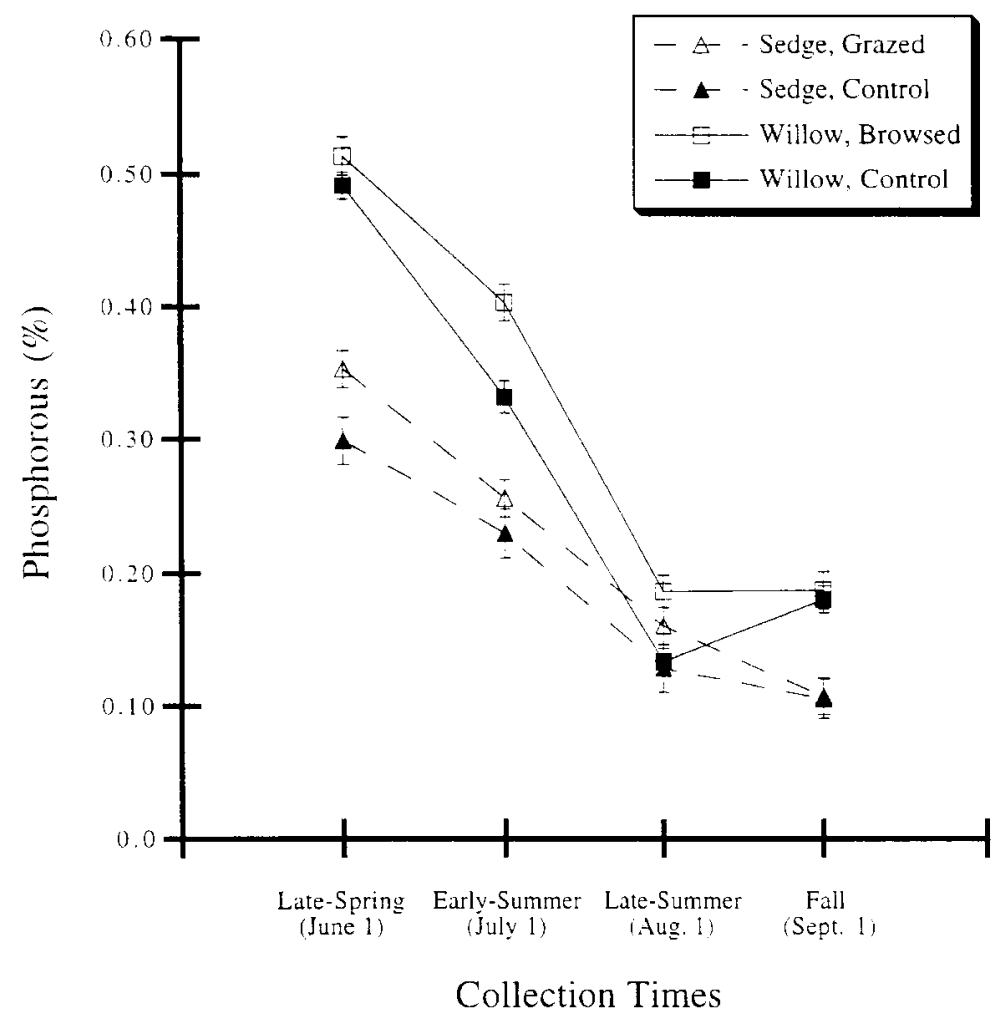

Fig. 2. Phosphorous concentration in current year's growth for grazed and ungrazed plants of 2 riparian species, water sedge (Carex aquatilus) and planeleaf willow (Salix planifolia). Data points represent means ( \pm standard error) for the dates that samples were collected. Collection times correspond with the following seasons: late-spring (1 June), early-summer (July 1), late-sumer (1 Aug.), and fall (1 Sept.).

sedge leaf and stem $\mathrm{P}$ concentration diminished by the end of the growing season. Digestibility of grazed water sedge was also greater than in plants that were not previously grazed (Fig. 3). Differences in IVDMD from 2.9 to $6.3 \%$ were found between grazed and ungrazed water sedge, and grazed plants had consistently higher digestibility at each collection time than did ungrazed plants.

The higher forage quality found in grazed water sedge as compared with ungrazed control plants is in agreement with several greenhouse and field experiments where other defoliated graminoids have been studied (Ruess and McNaughton 1984, McNaughton and Chapin 1985, Jaramillo and Detling 1988, Polley and Detling 1988). In these studies the samples were collected within the same season of treatment and imply that intensive grazing or clipping removes older growth and facilitates the subsequent replacement by younger tissue with lower C: $\mathrm{N}$ ratios (Jameson 1963). In this study samples were gathered the year following cattle use, and represented current year's growth that was not grazed the year of collection. Additionally, there was significantly higher production of sedges in previously grazed paddocks as compared with ungrazed controls (Schenck 1996, pers. comm.), thereby repudiating the probability that nutrients in the ungrazed standing-crop were diluted by greater aboveground biomass. Other comparable results are not available, so we suggest that these protracted responses may be attributed to water sedge nutrient storage strategies, accelerated mineralization in soils of grazed paddocks and increased nutrient availability, or altered riparian nutrient-cycling dynamics in grazed paddocks as compared with controls.

\section{Planeleaf Willow}

Data analysis for $\mathrm{N}$ and $\mathrm{P}$ concentrations in planeleaf willow indicated that these nutrients were not affected ( $p>0.10)$ by the season of cattle use 1 year after plants were browsed. Also, there were no significant collection times by grazing treatment interactions for $\mathrm{N}$ and $\mathrm{P}$ (Fig. 1 and 2). However, there was a significant $(p<0.01)$ collection time by browsing treatment interaction for IVDMD of planeleaf willow $\left(\underline{\mathrm{F}}_{12,22}=7.53\right)$. Browsed willow had greater digestibility during early growth and senescence than during the middle of the growing season (Fig. 3). Digestibility of browsed willow remained the same between late-summer and fall, while IVDMD of unbrowsed willow dropped substantially over the same period of time. The disparate effects of time describe this interaction and illustrate how seasonal nutritive trends may change as a result of cattle use the previous year. The simple effect of treatment varied between browsed and unbrowsed willow IVDMD in the fall. Browsed willow was higher $(p<0.10)$ in IVDMD than unbrowsed willow at this time $\left(\underline{\mathrm{F}}_{4,10}=4.6\right)$.

Data for planeleaf willow nutritive characteristics with time in the literature are lacking. Nitrogen concentration and digestibility among browse species have been reported under natural and simulated browsing, but these data represent individual points in time with browsing treatments that varied considerably from those in this present study. Nonetheless, previous research does provide a framework for comparison. For example, nitrogen concentrations in forage for Betula pubescens (Ehrh.) of 1.6 to $2.4 \%$ have been reported, along with pepsin/cellulase digestibility values of 48-49\% (Danell and Huss-Dannell 1985). Forage quality variables have also been determined for Salix spp. in Yellowstone National Park (Singer et al. 1994). They found nitrogen concentrations of 1-2\% and dry-matter digestibility values from $45-53 \%$ for several willow species. These IVDMD and $\mathrm{N}$ data were collected in August and are comparable to the IVDMD and $\mathrm{N}$ data found in August for planeleaf willow in our study.

Data for planeleaf willow $\mathrm{N}$ and $\mathrm{P}$ concentrations were reported for leaf samples taken at Sheep Creek from July-September 1994 and 1995 by Dernburg (1997). The P concentrations from leaf expansion to senescence were $0.32-0.27 \%$ and $\mathrm{N}$ concentrations over the same time period ranged from 2.4 to $1.8 \%$. These values are slightly lower than those determined in this study, but year-to-year variation is expected.

A univariate analysis that contrasted browsed planeleaf willow plants with 
those that were not browsed showed that $\mathrm{N}$ and $\mathrm{P}$ concentrations were not different $(p>0.10)$ over all collection times the year after grazing treatments were applied (Fig. 1 and 2). The IVDMD time by treatment interaction precluded the use of this univariate model, but the presence of this interaction indicated differences between browsed and unbrowsed willow through time. Browsed willow collected in the fall was $11 \%$ more digestible than unbrowsed willow collected at the same time (Fig. 3).

Forage quality differences have been reported to differ for some woody browse species as affected by defoliation intensities (Bryant 1981, Danell et al. 1985, Danell and Huss-Danell 1985, Singer et al. 1994). Moderate to high levels of browsing have resulted in increased leaf $\mathrm{N}$ and dry-matter digestibility (Danell and Huss-Danell 1985), lower IVDMD and tannins (Singer et al. 1994), and increased palatability (Danell et al. 1985) among woody species. Again, these responses were measured during the same growing season as when plants were browsed or were under continuous use. These increases, then, may not be meaningful in comparison with results from this study when plant responses were measured in the growing season after browsing.

\section{Species Comparisons}

Water sedge and planeleaf willow $\mathrm{N}$, $\mathrm{P}$, and IVDMD were different $(\mathrm{p}<0.01)$ from one another $\left(\underline{F}_{1,11}=566.6,93.3\right.$, 246.5, respectively). Averaged across all grazing treatments and controls, planeleaf willow contained $43 \%$ and $52 \%$ more forage $\mathrm{N}$ and $\mathrm{P}$ than did water sedge, while digestibility of water sedge was approximately $25 \%$ higher than that of planeleaf willow. Water sedge $\mathrm{N}$ and $\mathrm{P}$ concentrations were highly correlated $(\mathrm{r}=0.91)$, but this was not the case for planeleaf willow $(r=0.10)$. The gradual

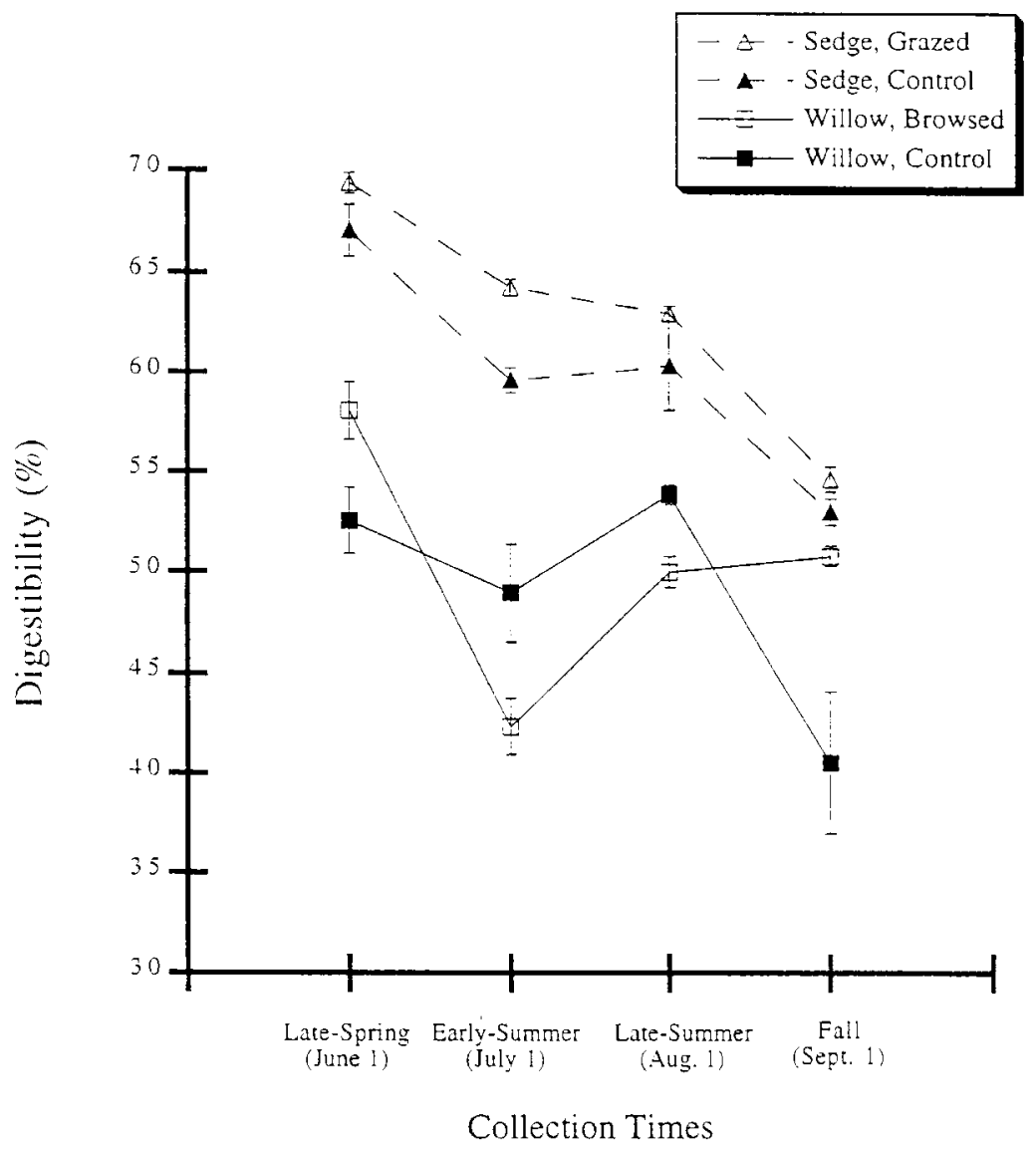

Fig. 3. In-vitro dry-matter digestibility of current year's growth for grazed and ungrazed plants of 2 riparian species, water sedge (Carex aquatilus) and planeleaf willow (Salix planifolia). Data points represent means $( \pm$ standard error) for the dates that samples were collected. collection times correspond with the following seasons: late-spring ( 1 June), earlysummer (1 July), late-summer (1 Aug.), and fall (1 Sept.). seasonal decline that was noted in water sedge $\mathrm{P}$ concentration did not parallel the steep decline that was found in planeleaf willow $\mathrm{P}$ concentration (Fig. 2). A grazing treatment $x$ species $x$ time of sampling interaction was found $(\mathrm{p}<0.01)$ for phosphorous $\left(\underline{F}_{12,61}=\right.$ 4.77) and IVDMD $\left(\underline{\mathrm{F}}_{14,81}=4.77\right)$ in the full model that included both species and treatments. This may be explained by differences in seasonal dynamics between the 2 species that caused the interaction. The decline in $\mathrm{P}$ concentration in willow plants between earlysummer and late-summer was greater than that found for water sedge. Also, differences in $\mathrm{P}$ between browsed and unbrowsed willow plants during the summer were greater, as compared with grazed and ungrazed water sedge plants. Seasonal differences also contributed similarly to the IVDMD grazing treatment $\mathrm{x}$ species $\mathrm{x}$ time interaction; for willow IVDMD varied more through time than the gradual changes found in water sedge (Fig. 3). These data reflect distinctive species-level responses among seasons that contributed to the significant 3-way interactions.

Species-level differences were also found as a result of varying effects that previous cattle use had on forage quality. Concentrations of $\mathrm{N}$ and $\mathrm{P}$ increased along with IVDMD in forage of water sedge as a result of previous grazing, while only fall IVDMD increased in planeleaf willow foliage the year following cattle use. The greatest increase in water sedge digestibility for grazed plants, compared with controls, was found in early-summer, while the greatest difference in willow digestibility was found in the fall. Grazed water sedge N and $\mathrm{P}$ concentrations were consistently higher than ungrazed control plants each season, while planeleaf willow $\mathrm{N}$ and $\mathrm{P}$ concentrations did not change from latespring to fall as a result of browsing the previous year.

The contrasting responses between this riparian sedge and shrub are evidence of variability associated with plant life forms that may represent adaptive strategies unique to each life form. Disparate strategies were demonstrated further by significant differences in $\mathrm{N}$ and $P$ concentrations and IVDMD between the 2 species throughout the growing season. Furthermore, although this willow and sedge are commonly associated with western riparian ecosys- 
tems (Youngblood et al. 1985), their nutritive responses to previous cattle use were quite different.

\section{Conclusions}

Forage quality of water sedge and planeleaf willow was affected the year following short-term, high-intensity cattle grazing in a montane riparian ecosystem, and the disparate responses were indicative of ecophysiological mechanisms unique to each life form. Increased N, P, and IVDMD in water sedge as a result of grazing the previous year may be evidence of increased uptake kinetics, greater nutrient availability, or reallocation of reserves. Greater IVDMD in browsed planeleaf willow in the fall may suggest lowered levels of fiber or secondary compounds, and may help explain greater cattle preference for the willow during later growth stages (Meyers 1989, Kinch 1989, Pelster 1998).

Season of use did not affect forage quality the following year, although season of use can affect other variables such as plant cover, production, and streambank erosion (Kauffman et al. 1983). These data demonstrated how grazing might interact with aboveground biomass production the following year in a riparian area on sites that have been excluded from grazing for an extended time, thereby improving graminoid forage quality in the year following cattle use. Conclusions are based on these one time, short-term, high-intensity cattle use treatments. Other cattle management regimes and other sites that are regularly grazed may not yield similar results. This study did demonstrate, however, that previous cattle use can increase forage quality of a montane riparian community, although substantiation with studies at different spatial and temporal scales and in other riparian areas is recommended.

Further field studies are needed to determine spatial and temporal variations in riparian nutrient dynamics and the extent of graminoid responses to herbivory. Ideally, a long-term study would include data collection prior to defoliation, during regrowth that season, and in new growth the following year. This experiment represents data for 1 growing season that encompassed only a commu- nity-level spatial scale in a montane riparian ecosystem. Clarification of how compensatory nutrient uptake and allocation patterns operate requires specieslevel, ecophysiological approaches be used that explore mechanisms that affect these response variables in the context of highly interactive soil-plant ecology. Evidence of higher forage quality in grazed water sedge in this study suggests that grazing induced a change in available nutrients and nutrient uptake in water sedge. A quantitative understanding of the underlying, indirect mechanisms will require greater study of the riparian soil-plant nutrient exchange complex.

\section{Literature Cited}

Baker D.E., G.W. Gorsline, C.G. Smith, W.I. Thomas, W.E. Grube and J.L. Ragland. 1964. Techniques for rapid analysis of corn leaves for eleven elements. Agron. J. 56:133-136.

Bryant, J.P. 1981. Phytochemical deterrence of snowshoe hare browsing in adventitious shoots of four Alaskan trees. Science 213:889-890.

Clary, W.P. 1995. Vegetation and soil responses to grazing simulation on riparian meadows. J. Range Manage. 48:18-25.

Coppock, D.L., J.K. Detling, J.E. Ellis, and M.I. Dyer. 1983. Plant-herbivore interactions in a North American mixedgrass prairie. Oecologia 56:1-9.

Danell, K. and K. Huss-Danell. 1985. Feeding by insects and hares on birches affected by moose browsing. Oikos 44: 75-81.

Danell, K., K. Huss-Danell, and R. Bergstrom. 1985. Interactions between browsing moose and two species of birch in Sweden. Ecol. 66:1867-1878.

Dernburg, A.R. 1997. Cattle preferences for willows (Salicaceae) in a montane riparian site. Ph.D. Diss.. Colorado State Univ., Fort Collins, Colo.

Jameson, D.A. 1963. Responses of individual plants to harvesting. Bot. Rev. 29:532-594.

Jaramillo, V.J. and J.K. Detling. 1988. Grazing history, defoliation, and competition: effects on shortgrass production and nitrogen accumulation. Ecol. 69:1599-1608.

Kauffman, J.B., W.C. Krueger, and M. Vavra. 1983. Effects of late season cattle grazing on riparian plant communities. J. Range Manage. 36: 685-691.

Kinch, G. 1989. Riparian area management: grazing management in riparian areas. USDI Bur. of Land Manage. Tech. Rep. 1737-4. U.S. Government Printing Office, Washington D.C.
Kinney, J.W. and W.P. Clary. 1994. A photographic utilization guide for key riparian graminoids. USDA Forest Ser. Gen. Tech. Rep. INT-GTR-308.

LECO Corporation. 1993. Instruction Manual CHN-1000 Elemental Analyzer. Form No. 200-516-014. Leco Corporation, St. Joseph, Mich.

McNaughton, S.J. and F.S. Chapin, III. 1985. Effects of phosphorous nutrition and defoliation on $\mathrm{C}_{4}$ graminoids from the Serengeti Plains. Ecol. 66:1617-1629.

Meyers, L.H. 1989. Grazing and riparian management in southwestern Montana. pp. 117-120. In: Practical Approaches to Riparian Resource Management- An Education Workshop. 8-11 May 1989; Billings, Mont. BLM-MT-PT-89-0014351.

Milchunas, D.G., A.S. Varnamkhasti, W.K. Lauenroth, and H. Goetz. 1995. Forage quality in relation to long-term grazing history, current-year defoliation, and water resource. Oecologia 101:366-374.

National Climatic Data Center. 1948-1990. NCDC Summary of the Day, West 1. Earth Info. Inc., Boulder, Colo.

NOAA (National Oceanic Atmospheric Administration). 1995-1996. Climatological Data. Red Feather Lakes, Colorado. U.S. Dept. of Commerce, Ashville, N.C.

Pearson, H.A. 1970. Digestibility trials: in vitro techniques. pp. 85-92. In: Range and Wildlife Habitat Evaluation-A Research Symposium. May, 1968, Flagstaff, Ariz.USDA Forest Ser. Misc. Publ. No. 1147.

Pelster, A.J. 1998. Diet selection and livestock management in a montane riparian zone. M.S. Thesis. Colorado State Univ., Fort Collins, Colo.

Platts, W.S. 1986. Managing riparian stream habitats. pp. 81-86. In: Proceeding of the Symposium, American Fisheries Society. March 5-6, 1986; Fort Collins, Colo. USDA Forest Ser. Intermountain Res. Sta., Boise, Ida.

Platts, W.S. and R.L. Nelson. 1985. Streamside and upland vegetation use by cattle. Rangelands 7: 5-7.

Polley, H.W. and J.K. Detling. 1988. Defoliation, nitrogen, and competition: effects on plant growth and nitrogen nutrition. Ecol. 70:721-727.

Popolizio, C.A., H. Goetz, and P.L. Chapman. 1994. Short-term response of riparian vegetation to 4 grazing treatments. J. Range Manage. 47:48-53.

Rhodes, B.D. and S.H. Sharrow. 1990. Effect of grazing by sheep on the quantity and quality of forage available to big game in Oregon's Coast Range. J. Range Manage. 43:235-237.

Roath, L.R. and W.C. Krueger. 1982. Cattle influence on a mountain riparian zone. J. Range Manage. 35:100-104. 
Ruess, R.W. and S.J. McNaughton. 1984. Urea as a promotive coupler of plant-herbivore interactions. Oecologia 63:331-337.

Ryder, R.A. 1980. Effects of grazing on bird habitats. pp. 51-66. In: Management of Western Forests and Grasslands for Nongame Birds. USDA Forest Ser. Gen. Tech. Rep. INT-86.

SAS Institute. 1996. SAS user's guide. Raleigh, N.C.

Schenck, S. 1996. Personal communication. Rangeland Ecosystem Science Dept., Colorado State Univ., Fort Collins, Colo.
Schulz, T.T. and W.C. Leininger. 1990. Differences in riparian vegetation structure between grazed areas and exclosures. J. Range Manage. 43:295-299.

Schulz, T.T. and W.C. Leininger. 1991. Impacts of livestock grazing on nongame wildlife populations in a montane riparian area. Great Basin Natur. 51:286-292.

Singer, F.J., L.C. Mark, and R.C. Cates. 1994. Ungulate herbivory of willows on Yellowstone's northern range. J. Range Manage. 47:435-443.
Tilley, J.M. and R.A. Terry. 1963. A twostage technique for the in vitro digestion of forage crops. J. Brit. Grassl. Soc. 18:104-111.

USDA, Soil Conservation Service and Forest Service. 1980. Soil survey report. Larimer County area, Colorado. Naz 70 soil series. U.S. Government Printing Office 239-812/48. Washington, D.C.

Youngblood, A.P., W.G. Padgett, and A.H. Wilson. 1985. Riparian type classification of eastern Idaho-western Wyoming. USDA Forest Ser. Region 4, R4-Ecol-8501. 